(RESEARCH ARTICLE)

\title{
The identification of fungi colonies total on the rumen content of cow and buffalo with addition of leaves and oil palm frond
}

\author{
Tri Astuti ${ }^{1,}{ }^{*}$, Syahro Ali Akbar ${ }^{1}$ Delsi Afrini ${ }^{2}$, M. Nasir Rofiq ${ }^{3}$ and Irna Humaira 4 \\ ${ }^{1}$ Department of Animal Science, Faculty of Agriculture University of Mahaputra Muhammad Yamin, Jenderal Sudirman \\ Street No 6 Solok City, West Sumatera. Indonesia. \\ 2 Department of Agribisnis, Faculty of Agriculture University of Mahaputra Muhammad Yamin, Jenderal Sudirman Street \\ No 6 Solok City, West Sumatera, Indonesia. \\ ${ }^{3}$ Agency for The Assessment and Application of Technology, Indonesia. \\ ${ }^{4}$ Biology Laboratorium, Regional X Higher Education Service Institutions.
}

Publication history: Received on 18 xNovember 2020; revised on 26 November 2020; accepted on 28 November 2020

Article DOI: https://doi.org/10.30574/wjarr.2020.8.2.0444

\begin{abstract}
This research aimed to determine the fungi colonies total on the rumen content of cattle and buffaloes with the addition of leaves and oil palm fronds incubated for 7 days. Each of the contents of the rumen was added with molasses, soybean soaking water as an energy source for microorganisms, as well as the addition of oil palm fronds and palm leaves to expect the type of fungus that is expected to grow. Calculation of the total colonies fungi in the rumen contents was carried out using total plate count with the dilution method. Complete Random Design by Factorial used to analyze the statistic data. Factor A was the type of rumen content (A1 = rumen of cattle, A2 = buffalo rumen), factor B was the addition of palm fronds (B1 = only rumen contents, B2 = palm oil fronds, B3 = palm leaves, and B4 = palm oil fronds and palm leaves). The results showed that the total number of fungal colonies was significantly higher in the rumen contents of cattle with an average of $509.17104 \mathrm{CFU} / \mathrm{ml}$. The highest total number of fungal colonies was found in rumen contents with the addition of palm oil fronds, with an average colony number of $655.83 \times 104 \mathrm{CFU} / \mathrm{ml}$, while the lowest was found in buffalo rumen contents with the addition of palm fronds and palm leaves (106.67x104 CFU / ml). The addition of oil palm fronds and palm leaves to the rumen contents did not have a different effect $(p>0.05)$.
\end{abstract}

Keywords: Fungi Colonies Total; Rumen Content

\section{Introduction}

Ruminant animal slaughter is increasing all the time, in line with the increasing human needs with ruminant meat food. This slaughtering process has waste the contents of the rumen that are not utilized and only constitutes the waste of slaughterhouses in each regency and city that has the potential to pollute the environment. The rumen is the largest part of the stomach of ruminant animals and have microbial community consisting of bacteria, protozoa, and fungi. Rumen microbes have a very important role for livestock because they can utilize plant nutrients efficiently as a source of energy, therefore the rumen contents can still be used as local microorganisms to increase the nutritional value of feed ingredients. Rumen fluid is rich in fiber and vitamin degrading enzymes. Rumen fluid also contains the enzymes aamylase, galactosidase, hemicellulase, cellulase, and xylanase (Williams and Withers, 1992). Rumen fluid enzymes as an alternative technology that can be used in hydrolyzing crude fiber and increasing the nutritional value of local feed raw materials (Pamungkas, 2012). This research aimed to use the rumen as an inoculum that can be used to ferment fiber source material so that the material is more easily digested and used as animal feed ingredients. The data on

\footnotetext{
${ }^{*}$ Corresponding author: Tri Astuti

Department of Animal Science, Faculty of Agriculture University of Mahaputra Muhammad Yamin, Jenderal Sudirman Street No 6 Solok City, West Sumatera. Indonesia.
} 
rumen microbial diversity and their interactions are still very limited until now. The condition of rumen microbes on anaerobic is one of due factors difficulty of culturing. This research made the rumen a source of local microorganisms (MOL) by incubating the rumen contents using molasses and the water boiled soybean (waste of tofu produce) as an energy source of microorganisms on the anaerobic condition. State of Sumarsih (2007), Microbes need a lot of nutrients to synthesize protoplasm and other cell parts, and they need a different nutrient for each. Radji (2011) nutritional media could be liquid and solids. The MOL be added with leaves, and oil palm fronds as the source of fiber, so it wishing that the microbes developed are fiber digesting microbes. Therefore, the fungi total colonies of Rumen be counted were calculated by the Total Plate Count (TPC) test method.

\section{Material and methods}

\subsection{The Materials of fermentation process}

The rumen contents were collected from the slaughterhouse and placed in tubes, be added molasses and air rendaman tahu water as the feeding of microorganisms in rumen content and then incubated for 10 days under anaerobic conditions. This mixture called Local microorganisms Astuti et al (2016). The experimental results revealed that there were 8 thermophilic bacteria isolates from the rumen The Local microorganism rumen contents samples were calculated the fungi colonies total using the Total Plate Count method. Samples are diluted in the range of 10-1 - 10-4 to assist in colony counting (Lay, 1994). The growth of fungi was pile up making it difficult for count colonies to do when the dilution is not carried out. The dilution was carried out by transferring $1 \mathrm{~mL}$ of the sample with a sterile pipette into a $9 \mathrm{~mL}$ sterile distilled solution to obtain $10^{-1}$ dilution, then transfer $1 \mathrm{ml}$ of the $10^{-1}$ dilution suspension with a sterile pipette to sterile distilled water to obtain a $10^{-2}$ dilution, so forward that the 10-4 dilution. The sample was put into Petri dishes contained 450 PCA temperatures that had been sterilized previously. Then the petri dish is immediately shaken while being opened so that the sample is spread evenly. Then do the calculation. Experimental design.

The research method that was used a descriptive method, which was the result of a TPC fungi total colonies description of the cattle rumen and buffalo rumen. A complete design random with Factorial was using as statistic analysis. Factor A was the type of rumen content ( $A 1=$ rumen of cattle, $A 2=$ buffalo rumen), factor $B$ was the adding of a palm frond (B1 = rumen content only, B2 = oil palm frond, B3 = palm leaf, and B4 = leaf and oli palm frond).

All data were subjected to a one-way analysis of variance (Steel, Torrei, \& Dickey, 1997), while significant differences were further tested using Duncan's multiple range test at $5 \%$ level of significance.

\section{Results and discussion}

The results of calculating the fungi total colonies on Mol rumen contents at each dilution can be seen in Table 1, and the results of the statistical test of the study at $10^{-4}$ dilutions showing in Table 2 .

Based on Table 1 can be seen that the dilution $10^{-1}$ on MOL rumen contents of cattle and buffalo show an infinite of count fungal colonies total. The Mol of cow's rumen still shows an infinite number of counts up to $10^{-3}$ dilution, while in the Mol buffalo's rumen at $10^{-3}$ dilution there were no more counts that shown an infinite of colonies. This was shown that the fungi in the rumen contents of cattle were more developed than the contents of buffalo rumen. The cow's rumen fluid, containing rumen microbes and enzymes secreted by rumen microbes, and food substances have been modified by rumen microbes, enzymes, vitamins, and minerals (Budiansyah et al, 2011). In this research, the rumen contents were given molasses and soya boiled water as a source of nutrition and it was assumed that these materials could be a energy microbe and stimulate for developed. Pujaningsih, (2006) state the molasses include $20 \%$ water, $3.5 \%$ protein, $58 \%$ carbohydrate, $0.80 \% \mathrm{Ca}, 0.10 \%$ phosphorus, and $10.50 \%$ other mineral ingredients.

Ogimoto and Imai, (1980) the ruminants have four beneficial microbial types, namely bacteria, protozoa, fungi, and the bacteria have the highest species and population. Mc Donald, (1988) state the fungus was found in cattle pastored and as a cellulolytic group. The energy source provided for this MOL rumen research was thought could be to facilitate the growth of fungi. 
Table 1 The Calculation of the Fungal Colonies Total on MOL Rumen with the Addition of Midribs and Oil Palm Leaves (CFU / gr)

\begin{tabular}{|c|c|c|c|c|c|c|c|c|}
\hline \multirow{2}{*}{$\begin{array}{l}\begin{array}{l}\text { The } \\
\text { treatments }\end{array} \\
\text { Dilution }\end{array}$} & \multicolumn{4}{|l|}{ Cow } & \multicolumn{4}{|c|}{ Bufallo } \\
\hline & $10^{-1}$ & $10^{-2}$ & $10^{-3}$ & $10^{-4}$ & $10^{-1}$ & $10^{-2}$ & $10^{-3}$ & $10^{-4}$ \\
\hline \multirow[t]{3}{*}{$\mathrm{B}_{1}$} & $\infty$ & $\infty$ & 697,5 & 451,5 & $\infty$ & $\infty$ & 205 & 180 \\
\hline & $\infty$ & $\infty$ & 724,5 & 415 & $\infty$ & 271 & 187 & 102 \\
\hline & $\infty$ & $\infty$ & $\infty$ & 798 & $\infty$ & $\infty$ & 173 & 148 \\
\hline \multirow[t]{3}{*}{$\mathrm{B}_{2}$} & $\infty$ & $\infty$ & $\infty$ & 939 & $\infty$ & 422 & 257 & 137 \\
\hline & $\infty$ & $\infty$ & 655,5 & 537,5 & $\infty$ & $\infty$ & 286 & 200 \\
\hline & $\infty$ & $\infty$ & $\infty$ & 491 & $\infty$ & $\infty$ & 373 & 104 \\
\hline \multirow[t]{3}{*}{$\mathrm{B}_{3}$} & $\infty$ & $\infty$ & $\infty$ & 166,5 & $\infty$ & 276 & 188 & 143 \\
\hline & $\infty$ & $\infty$ & $\infty$ & 582 & $\infty$ & 298 & 133 & 83 \\
\hline & $\infty$ & 607,5 & 249,5 & 202 & $\infty$ & 118 & 283 & 183 \\
\hline \multirow[t]{3}{*}{$\mathrm{B}_{4}$} & $\infty$ & $\infty$ & $\infty$ & 429 & $\infty$ & 297 & 247 & 43 \\
\hline & $\infty$ & $\infty$ & $\infty$ & 891,5 & $\infty$ & 477 & 192 & 84 \\
\hline & $\infty$ & 327 & 180 & 171 & $\infty$ & 499 & 263 & 193 \\
\hline
\end{tabular}

Note: B1 = rumen content only, B2 = oil palm frond, B3 = palm leaf, and B4 = leaf and oli palm frond, $\infty$ = Infinity

Table 2 Effect of addition of oil palm fronds and leaves on the Average Amount of Fungal Colonies Total on Mol Rumen (CFU / gr)

\begin{tabular}{|c|c|c|c|c|c|}
\hline \multirow[t]{2}{*}{ Factor A } & \multicolumn{4}{|c|}{ Factor B } & \multirow[t]{2}{*}{ Average } \\
\hline & $\mathrm{B}_{1}$ & $\mathrm{~B}_{2}$ & $\mathrm{~B}_{3}$ & $\mathrm{~B}_{4}$ & \\
\hline$P_{1}$ & 554,83 & 655,83 & 316,83 & 497,17 & $509,17^{\mathrm{A}}$ \\
\hline \multirow[t]{2}{*}{$\mathrm{P}_{2}$} & 143,33 & 147,00 & 136,33 & 106,67 & $142,22^{\text {в }}$ \\
\hline & 349,08 & 401,42 & 226,58 & 301,92 & \\
\hline
\end{tabular}

Statistical tests were only done on the number fungi total colonies with $10^{-4}$ dilution, this was due to the dilution of $10^{-}$ $1-10^{-3}$ were still many infinite number results of calculations, so it was rather difficult to do data processing. The various test results showed that there was no interaction effect between the rumen contents sources with the addition of different fiber sources, as well as the addition of oil palm fronds, palm leaves, and the combination of the two that were expected as a source of fiber and without giving anything had a no different effect on the total number of fungal colonies ( $p>0.05)$. Based on table 2 it shown that the type of rumen contents has a high significant affect $(p<0.01)$. The treatment P1 was the rumen contents of cattle showed a high significantly affect results than the contents of buffalo rumen (509.17 Vs. 142.22). The high significant effect was suspected be caused the protozoans were most microbe on the buffalo rumen than fungi, so the best environment for fungi was on cow's rumen. This opinion was similar to Jabari et al., (2014) stated that the protozoan population in buffalo rumen fluid contents was higher than cattle. This condition 
was likely to be the cause of a smaller amount of fungus in the contents of the buffalo rumen because it was already dominated by protozoa. The rumen contents of cattle better to be a source of microorganisms in the production of MOL inoculums. The data also shows that the fungal colonies total no affected with or without the addition of a source of palm fronds, but it is expected to affect the type of fungus that grows is a fiber-digesting fungus that can be utilized to facilitate processing of high-fiber feed ingredients.

\section{Conclusion}

The results of this study shown that The highest total number of fungal colonies was found in rumen contents with the addition of palm oil fronds, with an average colony number of $655.83 \times 104 \mathrm{CFU} / \mathrm{ml}$, while the lowest was found in buffalo rumen contents with the addition of palm fronds and palm leaves (106.67x104 CFU / ml).

\section{Compliance with ethical standards}

\section{Acknowledgments}

The authors are extremely grateful for the financial assistance from the Ministry of Research and

Technology of the Republic of Indonesia through Insinas Research 2020.

\section{Disclosure of conflict of interest}

This article written base on research without conflict interest.

\section{References}

[1] Astuti, T., Amir, Y., \& Santoso, U. Nutritional Improvement of Palm Oil Fronds for Ruminant Feedstuffs Using a Local Biotechnological Approach. 2016; 15(27):450-454

[2] Agus Budiansyah, Resmi, Nahrowi, Komang G. Wiryawan, Maggy T. Suhartono dan Yantyati Widyastuti. Karakteristik Endapan Cairan Rumen Sapi asal Rumah Potong Hewan sebagai Feed Supplement. Jurnal Ilmiah Ilmu-Ilmu Peternakan Mei 2011; Vol. XIV. No.1:Pp 1-13

[3] Jabari, S., M. Eslami, M. Chaji, T. Mohammadabadi, M. Bojarpour. Comparison digestibility and protozoa population of Khuzestan water buffalo and Holstein cow. Vet. Res. Forum. 2014; 5 (4):295 - 300.

[4] Ogimoto, K and Imai. 1980. Atlas of Rumen Microbiology. Japan Scientific Socitied Press. Tokyo

[5] Pamungka W. 2012. Penggunaan enzim cairan rumen sebagai alternatif untuk mendukung pemanfaatan bahan baku pakan ikan lokal. Media Akuakultur Volume 7 Nomor 1 Tahun 2012

[6] Pujaningsih, R. I. 2006. Pengelolaan Bijian pada Industri Makanan Ternak. Alif Press, Semarang.

[7] Radji, M., 2011, Buku Ajar Mikrobiologi Panduan Mahasiswa Farmasi dan Kedokteran, 107, 118, 201-207, 295 , Jakarta, Buku Kedokteran EGC

[8] Sumarsih,S. 2003.Mikrobiologi Dasar. Yogyakarta:UPN Veteran.I. S. Jacobs and C. P. Bean, "Fine particles, thin films and exchange anisotropy," in Magnetism, vol. III, G. T. Rado and H. Suhl, Eds. New York: Academic, 1963, pp. 271-350.

[9] Williams AG and SE Withers. Changes in the rumen microbial population and its activities during the refaunation period after the $r$ eintroduction of cilliate protozoa into the rumen of defaunated sheep. Can. J Microbiol 1992; 39:61-69 